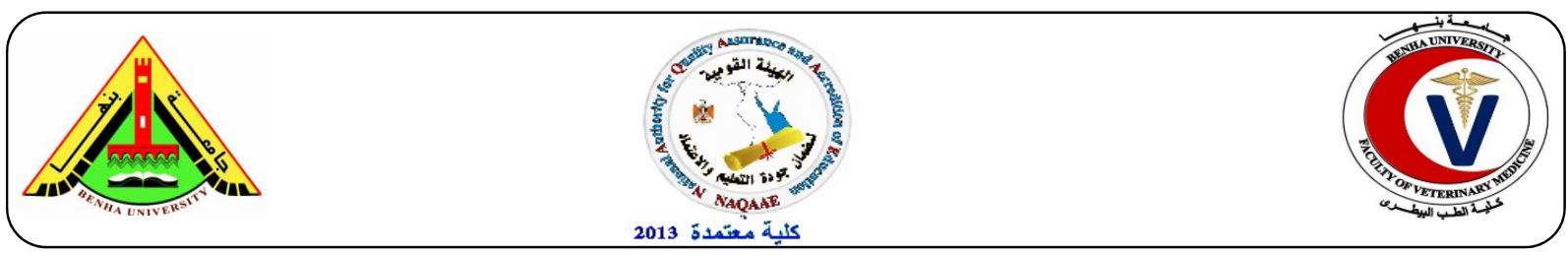

\title{
Environmental Factors Affecting Some Productive and reproductive Traits in Egyptian Buffaloes
}

\author{
Basant, M.N. ShafiK ${ }^{1}$; El-Bayomi, Kh. M. ${ }^{\text {; }}$ Abo-Salem, M.E.S. ${ }^{3}$ and Darwish, S.A. ${ }^{4}$ \\ ${ }^{1}$ Animal Wealth Development Dept., Fac. of Vet. Med., Benha Univ. \\ ${ }^{2}$ Animal Wealth Development Dept., Fac. of Vet. Med., Zagazig Univ. \\ ${ }^{3}$ Forensic Medicine Dept., Fac. of Vet. Med., Benha Univ. \\ ${ }^{4}$ Animal Production Research Institute, ARC., Ministry of Agriculture, Doki, Giza, Egypt.
}

\begin{abstract}
A B S T R A C T
This study was conducted to evaluate the effect of some environmental factors on milk production in Egyptian buffaloes and the effect of parity and season of calving on calving interval and days open. There was a significant effect of parity $(P \leq 0.05)$ on 305 day milk yield, while season of calving had a highly significant effect $(P \leq 0.01)$ on 305 day milk yield. Animals with age at first service less than 21 months and age at first calving less than 35 months had higher milk yield than other animals ( 2489.5 and $2526.7 \mathrm{~kg}$, respectively). With increasing days open, milk production increased so animals had more than 160 days open produced $2757.8 \mathrm{~kg}$ milk. Milk yield in winter $(2600.5 \mathrm{~kg})$ was higher than in summer season $(2441.5 \mathrm{~kg})$. Animals which conceived four or more services produce more milk yield $(2529.8 \mathrm{~kg})$. Season of calving had a significant effect $(P \leq 0.05)$ but parity had a highly significant effect $(P \leq 0.01)$ on calving interval and days open. There was direct relationship between milk yield with each of calving interval and days open. Animals that gave more than $3000 \mathrm{~kg}$ showed the maximum calving interval and days open (14 months and 111.8 days, respectively).
\end{abstract}

Keywords: calving interval, 305day milk yield, Egyptian buffaloes, Paritym Season of calving, Services.

(http://www.bvmj.bu.edu.eg)

(BVMJ-32(1): 153-159, 2017)

\section{INTRODUCTION}

Water buffaloes include river buffaloes and swamp buffaloes; the Egyptian buffaloes are the river type. It is a species of great economic value in Egypt due to it is a main source of milk and meat. Egyptian buffaloes can be classified according to their geographical locations into Beheiri, Balady and Menoufi which are found in North Egypt and Saiedy found in South Egypt (DAS-IS, 2004). There were nearly 195 million buffalo in the world, 97\% in Asia, 0.2\% in Europe mainly in Italy and $2 \%$ in Africa mainly in Egypt (FAO, 2013). Bovine species characterized by their high milk and meat production also their tolerance to hot environmental condition, draught ability and a reasonable growth rate on roughage feed so these animals mostly used in developing countries (Mondal et al., 2007). Reproductive efficiency of dairy animals has an effective role on the profitability of the dairy farm. Fertility traits as number of services per conception and days open play an effective role on productive life of animal. The short day's open and minimum number of services per conception increases productive life of the animal and the number of calf crops (Ali et al., 2011).

The objective of this study was: Determination of the effects of some environmental factors on milk production in Egyptian buffaloes such as age at first service, age at first calving, calving interval, days open or service period, number of services per conception, dry period and season of calving. A. Determination of the effects of some environmental factors on calving interval and days open such as parity and season of calving. B. To determine the relationship between the level of production and fertility traits.

\section{Material and methods}

The data used in the present study were collected from the productive and reproductive records of Egyptian buffaloes maintained at Mahalet-Mousa experimental farms of Animal Production Research Institute (APRI), Agricultural Research Centre, Ministry of Agriculture. Animals were fed on a balanced ration covering all 
requirements of them either the maintenance or milk production requirements according to the recommendation of (APRI, 1997). Heifers were naturally served for the first time when they reach 24 month of age and or 300 to $350 \mathrm{~kg}$ of body weight.

\subsection{Studied traits:}

\subsubsection{Non-genetic factors affecting milk production traits:}

1. Parity. 2. Age at first service. 3. Age at first calving. 4. Calving interval. 5. Days open. 6. Number of services /conception. 7. Dry period. 8. Season of calving.

\subsubsection{Factors affecting calving interval and days open:}

1. Season of calving. 2. Parity.

\subsubsection{Level of production in relation to fertility traits:}

1. Number of services/conception. 2. Age at first service. 3. Age at first calving. 4. Calving interval. 5. Days open.

\subsection{2. Statistical Data Analysis:}

\subsubsection{Least squares analysis of covariance:}

All data were analyzed using GLM model of SAS (SAS, 2001) for non-genetic factors.

\subsubsection{First model:}

To analyze the factors affecting on 305day milk yield in the present investigation, the following model was assumed. $Y_{i j k l m n o p}=\mu+P_{i}+$ $A F S_{j}+A F C_{k}+C I_{l}+D O_{m}+S / C_{n}+D P_{o}+S_{p}+b_{l}$

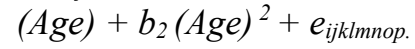

Where:- $\mathrm{Y}_{\mathrm{ijk} k \mathrm{mnop}}$ : The observed value; (i.e. total milk yield and 305 milk yield), $\mu$ : The overall mean, $\mathrm{P}_{\mathrm{i}}$ : The effect of the $\mathrm{i}^{\text {th }}$ parity; $(\mathrm{i}=1,2,3$ and 4 , whereas $1=$ first parity, $2=$ second parity, $3=$ third parity and $4=$ fourth parity or more), $\mathrm{AFS}_{\mathrm{j}}$ : The effect of the $\mathrm{j}^{\text {th }}$ age at first service; $(\mathrm{j}=1,2$ and 3 , whereas $1=$ less than 21 months, $2=21-25$ months, and $3=$ =more than 25 months), $\mathrm{AFC}_{\mathrm{k}}$ : The effect of the $\mathrm{k}^{\text {th }}$ age at first calving; $(\mathrm{k}=1,2$ and 3 , whereas $1=$ less than 35 months, $2=35-40$ months, and $3=$ more than 40 months), $\mathrm{CI}_{1}$ : The effect of the $1^{\text {th }}$ calving interval; ( $1=1,2$ and 3 , whereas $1=11$ to 12 months, $2=13-15$ months, and $3=$ more than 15 months), $\mathrm{DO}_{\mathrm{m}}$ : The effect of the $\mathrm{m}^{\text {th }}$ days open; $(\mathrm{m}=1,2,3$ and 4 , whereas $1=$ less than 60 days, $2=60$ to 109 days, $3=110-160$ days, and $4=$ more than 160 days), $S / C_{n}$ : The effect of the $n^{\text {th }}$ number of services/conception; $(\mathrm{n}=1,2,3$ and 4 , whereas $1=$ one service, $2=$ two services, $3=$ three services, $4=$ four and more services), $\mathrm{DP}_{\mathrm{o}}$ : The effect of the $\mathrm{o}^{\text {th }}$ dry period; $(\mathrm{o}=1,2$ and 3 , whereas $1=$ less than 170 days, $2=170-230$ days, and $3=$ more than 230 ), $\mathrm{S}_{\mathrm{p}}$ : The effect of the $\mathrm{p}^{\text {th }}$ season of calving; $(\mathrm{p}=1,2$, 3 and 4 , whereas $1=$ summer season, $2=$ winter season, $3=$ autumn season and $4=$ spring season), $b_{1}$ and $\mathrm{b}_{2}$ : partial linear and quadratic regression coefficients of $\mathrm{Y}_{\mathrm{ijk} k \mathrm{mnop}}$ on age at calving and $\mathrm{e}_{\mathrm{ijklmnop}}$ : random error.

\subsubsection{Second model:}

This model used to analyze the factors affecting on calving interval and days open in the present investigation, the following model was assumed. $Y_{i j}=\mu+S_{i}+P_{j}+e_{i j .}$. Where: $-\mathrm{Y}_{\mathrm{ij}}$ : The observed value; (i.e. calving interval and days open), $\mu$ : The overall mean, $\mathrm{S}_{\mathrm{i}}$ : The effect of the $\mathrm{i}^{\text {th }}$ season of calving; ( $\mathrm{i}=1,2,3$ and 4 , whereas $1=$ summer season, $2=$ winter season, $3=$ autumn season and $4=$ spring season), $P_{j}$ : The effect of the $j^{\text {th }}$ parity; $(j=$ 1,2 and 3 , whereas $1=$ second parity, $2=$ third parity and $3=$ fourth parity or more), $\mathrm{e}_{\mathrm{ij}}$ : random error.

\subsubsection{Third model:}

This model used to analyze the effect of level of production on fertility traits in the present investigation, and the following model was assumed.

Table (1): Analysis of Variance of Factors Affecting 305-Day Milk Yield

\begin{tabular}{|c|c|c|c|}
\hline S.O.V & D.F & M.S & F-Value \\
\hline Parity. & 3 & 680102.27 & $2.82 *$ \\
\hline Age at First service. & 2 & 21735.59 & 0.09 \\
\hline Age at First calving. & 2 & 485449.57 & 2.01 \\
\hline Calving Interval. & 2 & 602970.59 & 2.49 \\
\hline Days Open (days). & 3 & 427965.41 & 1.77 \\
\hline Number of Services Per Conception (S/C). & 3 & 364393.94 & 1.51 \\
\hline Dry Period. & 2 & 489455.90 & 2.03 \\
\hline Season of Calving. & 3 & 1960535.80 & $8.12 * *$ \\
\hline Age at Calving. & 1 & 307415.15 & 1.27 \\
\hline Age at Calving 2 . & 1 & 320601.80 & 1.33 \\
\hline Experimental error & 937 & 241323.3 & \\
\hline
\end{tabular}


$Y_{i}=\mu+L_{i}+e_{i}$. Where: $-\mathrm{Y}_{\mathrm{i}}$ : The observed value; (i.e. service per conception, age at first service, age at first calving, calving interval and days open), $\mu$ : The overall mean, $\mathrm{L}_{\mathrm{i}}$ : The effect of the $\mathrm{i}^{\text {th }}$ level of production (305DMY); ( $\mathrm{i}=1,2$ and 3 , whereas $1=$ less than $2000 \mathrm{~kg}, 2=2000-3000 \mathrm{~kg}$ and $3=$ more than $3000 \mathrm{~kg}$ ) and $\mathrm{e}_{\mathrm{i}}$ : random error.

Table (2): Least Squares Means, Standard Errors of Various Factors Affecting 305-Day Milk Yield

\begin{tabular}{|c|c|c|}
\hline Classification & $\mathrm{N}$ & L.S.M \pm S.E \\
\hline \multicolumn{3}{|l|}{ Parity. } \\
\hline The $1^{\text {stlactation }}$ & 144 & $2294.25^{\mathrm{b}} \pm 93.22$ \\
\hline The $2^{\text {nd }}$ lactation & 165 & $2506.63^{\mathrm{a}} \pm 54.64$ \\
\hline The $3^{\text {rd }}$ lactation & 151 & $2526.05^{\mathrm{a}} \pm 43.82$ \\
\hline The $4^{\text {th }}$ lactation and more. & 495 & $2600.96^{a} \pm 55.14$ \\
\hline \multicolumn{3}{|l|}{ Age at First Service (months). } \\
\hline Less than 21. & 487 & $2487.74^{\mathrm{a}} \pm 34.54$ \\
\hline $21-25$ & 204 & $2468.63^{\mathrm{a}} \pm 45.46$ \\
\hline \multicolumn{3}{|l|}{ More than 25 . } \\
\hline \multicolumn{3}{|l|}{ Age at First Calving (months). } \\
\hline Less than 35 . & 343 & $2448.42^{\mathrm{a}} \pm 37.74$ \\
\hline $35-40$. & 210 & $2470.72^{a} \pm 39.68$ \\
\hline \multicolumn{3}{|l|}{ More than 40.} \\
\hline Calving Interval (months). & 331 & $2548.77^{a} \pm 66.23$ \\
\hline $11-12$. & 330 & $2664.75^{\mathrm{a}} \pm 47.88$ \\
\hline $13-15$. & 150 & $2477.72^{a} \pm 96.97$ \\
\hline \multicolumn{3}{|l|}{ More than 15.} \\
\hline \multicolumn{3}{|l|}{ Days Open (days). } \\
\hline Less than 60 . & 264 & $2521.75^{\mathrm{ab}} \pm 58.09$ \\
\hline $60-109$ & 148 & $2479.26^{b} \pm 65.19$ \\
\hline $110-160$ & 149 & $2757.89^{\mathrm{a}} \pm 98.78$ \\
\hline \multicolumn{3}{|l|}{ More than 160 . } \\
\hline \multicolumn{3}{|l|}{ Number of Services/Conception } \\
\hline One Service. & 252 & $2443.99^{\mathrm{a}} \pm 39.13$ \\
\hline Two Services. & 86 & $2524.54^{\mathrm{a}} \pm 56.71$ \\
\hline Three Services. & 101 & $2529.84^{\mathrm{a}} \pm 51.77$ \\
\hline \multicolumn{3}{|l|}{ Four Services and more. } \\
\hline \multicolumn{2}{|l|}{ Dry Period (days). } & $2624.10^{\mathrm{a}} \pm 48.59$ \\
\hline Less than 170. & 254 & $2580.05^{\mathrm{a}} \pm 43.76$ \\
\hline $170-230$ & 260 & $2487.10^{\mathrm{a}} \pm 40.36$ \\
\hline \multicolumn{3}{|l|}{ More than 230.} \\
\hline $\begin{array}{l}\text { Season of Calving. } \\
\text { Summer. }\end{array}$ & 239 & $2441.52^{\mathrm{bc}} \pm 40.45$ \\
\hline Winter. & 191 & $2600.54^{a} \pm 44.19$ \\
\hline Autumn. & 374 & $2385.48^{c} \pm 36.67$ \\
\hline Spring. & 151 & $2500.36^{\mathrm{ab}} \pm 46.07$ \\
\hline
\end{tabular}

Within the same classification, the appearances of least square means with the different letters are significantly different $(p \leq 0.05)$. Otherwise, they do not. 


\section{RESULTS}

Table (1) showed a significant effect of parity $(P \leq 0.05)$ on 305 -day milk yield, while season of calving had a highly significant effect $(P \leq 0.01)$ on 305day milk yield. Table (2) mentioned that animals with age at first service less than 21 months, age at first calving less than 35 months and animals with days in milk less than 180 days had the highest milk yield. Also, animals with days open more than 160 days and with dry period less than 170 days showed the highest milk production. Table (3) noted that season of calving had a significant effect $(P \leq 0.05)$ on calving interval and days open. Moreover, parity had a highly significant effect $(P \leq 0.01)$ on calving interval and days open. Table (4) showed that summer season had the highest calving interval and days open than winter. With increasing lactation season, calving interval and days open decreased. Table (5) showed that a significant effect $(P \leq 0.05)$ between AFC and level of production. While, there was a non-significant effect between each of AFS, CI, $\mathrm{DO}$ and number of services per conception with the level of production. Table (6) showed that animals that produced more than $3000 \mathrm{~kg}$ of milk per season showed the lowest age at first service and calving, while showed the highest number of services per conception, calving interval and days open.

Table (3): Analysis of Variance of Season of Calving and Parity Affecting Calving Interval and Days Open.

\begin{tabular}{|c|c|c|c|c|c|c|}
\hline \multirow[t]{2}{*}{ S.O.V } & \multicolumn{3}{|c|}{ Calving Interval } & \multicolumn{3}{|c|}{ Days Open } \\
\hline & D.F & M.S & F-Value & D.F & M.S & F-Value \\
\hline Season of Calving & 3 & 25.40 & $2.91 *$ & 3 & 19136.05 & $2.52 *$ \\
\hline Parity & 2 & 600.81 & $68.87 * *$ & 2 & 500075.30 & $65.87 * *$ \\
\hline Experimental error & 1067 & 8.72425 & & 1065 & 7592.169 & \\
\hline
\end{tabular}

Table (4): Least Squares Means, Standard Errors of Season of Calving and Parity Affecting Calving Interval and Days Open.

\begin{tabular}{|c|c|c|c|}
\hline \multirow[t]{2}{*}{ S.O.V } & \multicolumn{2}{|c|}{ Calving Interval } & \multirow[t]{2}{*}{ Days Open } \\
\hline & $\mathrm{N}$ & L.S.M \pm S.E & \\
\hline \multicolumn{4}{|l|}{ Season of Calving. } \\
\hline Summer. & 247 & $14.79^{\mathrm{a}} \pm 0.19$ & $135.88^{a} \pm 5.7$ \\
\hline Winter. & 224 & $14.55^{\mathrm{ab}} \pm 0.20$ & $124.26^{\mathrm{ab}} \pm 6.0$ \\
\hline Autumn. & 451 & $14.31^{\mathrm{b}} \pm 0.14$ & $118.92^{\mathrm{b}} \pm 4.4$ \\
\hline Spring. & 151 & $15.05^{\mathrm{a}} \pm 0.24$ & $134.21^{\mathrm{ab}} \pm 7.3$ \\
\hline \multicolumn{4}{|l|}{ Parity. } \\
\hline The $2^{\text {nd }}$ lactation & 232 & $16.29^{\mathrm{a}} \pm 0.19$ & $175.13^{\mathrm{a}} \pm 5.9$ \\
\hline The $3^{\text {rd }}$ lactation & 185 & $14.08^{\mathrm{b}} \pm 0.22$ & $111.06^{\mathrm{bc}} \pm 6.5$ \\
\hline The $4^{\text {th }}$ lactation and more. & 656 & $13.65^{\mathrm{bc}} \pm 0.12$ & $98.76^{c} \pm 3.5$ \\
\hline
\end{tabular}

Table (5): Analysis of Variance of Level of Production in Relation to Fertility Traits.

\begin{tabular}{lllcccc}
\hline S.O.V & $\begin{array}{l}\text { Service } \\
\text { Conception }\end{array}$ & Per & $\begin{array}{l}\text { Age at } \\
\text { service }\end{array}$ & $\begin{array}{l}\text { First } \\
\text { calving }\end{array}$ & $\begin{array}{l}\text { at } \\
\text { Interval }\end{array}$ & Days Open \\
\hline D.F & 2 & 2 & 2 & 2 & 2 \\
M.S & 0.439219 & 11.84224 & 98.99364 & 4.598312 & 6170.048 \\
F-Value & 0.30 & 0.88 & $3.60 *$ & 0.53 & 0.85 \\
S.O.V & Experimental error & & & 808 & 808 \\
D.F & 952 & 952 & 952 & 8.654362 & 7298.682 \\
M.S & 1.454812 & 13.52532 & 27.52751 &
\end{tabular}


Table (6): Least Squares Means, Standard Errors of Level of Production in Relation to Fertility Traits.

\begin{tabular}{|c|c|c|c|c|c|c|c|}
\hline Classification & $\mathrm{N}$ & $\begin{array}{l}\text { Service per } \\
\text { conception } \\
\text { L.S.M } \pm \text { S.E }\end{array}$ & $\begin{array}{c}\text { AFS } \\
\text { L.S.M } \pm \text { S.E }\end{array}$ & $\begin{array}{c}\text { AFC } \\
\text { L.S.M } \pm \text { S.E }\end{array}$ & $\mathrm{N}$ & $\begin{array}{c}\text { CI } \\
\text { L.S.M } \pm \text { S.E }\end{array}$ & $\begin{array}{c}\text { DO } \\
\text { L.S.M } \pm \text { S.E }\end{array}$ \\
\hline $\begin{array}{l}\text { Level of } \\
\text { Production }(\mathrm{kg}) \\
\text { (305DMY). } \\
\text { - less than } 2000 \\
\text {-2000-3000 } \\
\text { - More than } 3000 \text {. }\end{array}$ & $\begin{array}{l}155 \\
673 \\
127\end{array}$ & $\begin{array}{l}1.76^{\mathrm{a}} \pm 0.09 \\
1.84^{\mathrm{a}} \pm 0.04 \\
1.86^{\mathrm{a}} \pm 1.07\end{array}$ & $\begin{array}{l}23.26^{\mathrm{a}} \pm 0.29 \\
23.11^{\mathrm{a}} \pm 0.14 \\
22.70^{\mathrm{a}} \pm 0.33\end{array}$ & $\begin{array}{l}37.32^{\mathrm{a}} \pm 0.42 \\
36.31^{\mathrm{b}} \pm 0.20 \\
35.70^{\mathrm{b}} \pm 0.46\end{array}$ & $\begin{array}{l}106 \\
582 \\
123\end{array}$ & $\begin{array}{l}13.71^{\mathrm{a}} \pm 0.28 \\
14.02^{\mathrm{a}} \pm 0.12 \\
14.06^{\mathrm{a}} \pm 0.27\end{array}$ & $\begin{array}{l}98.58^{\mathrm{a}} \pm 8.33 \\
109.48^{\mathrm{a}} \pm 3.56 \\
111.82^{\mathrm{a}} \pm 7.70\end{array}$ \\
\hline
\end{tabular}

Within the same classification, the appearances of least square means with the different letters are significantly different $(p \leq 0.05)$. Otherwise, they do not.

\section{DISCUSSION}

Parity had a significant effect $(P \leq 0.05)$ on 305 day milk yield. Fourth lactation season or more showed the maximum yield $(2600.9 \mathrm{~kg})$. The previous results are in agreement with those recorded by ((Mahdy et al., 2001), (Badran et al., 2002), (Thiruvenkadan and Panneerselvam, 2010), (Sohail, 2010) and (Eskandari and Karimpour, 2012)) who showed that there was an effect of parity on 305day milk yield. Age at first services had a non-significant effect on 305day milk yield. The maximum yield $(2489.5 \mathrm{~kg})$ was obtained at age 21-25-months and minimum yield was 2468.6 $\mathrm{kg}$ obtained at age less than 21 months. These results agreed with (Sohail, 2010) who found that age at puberty had a non-significant effect on 305day milk yield. Age at first calving had a nonsignificant effect on 305day milk yield. The maximum value of 305 day milk yield was 2526.7 $\mathrm{kg}$ obtained in animals calved for the first time at age less than 35 months. The previous results are in agreement with those recorded by (Thiruvenkadan et al., 2010) and (Sohail, 2010) showed that age at first calving had no significant effect on 305day milk yield. Calving interval had a non-significant effect on 305 day milk yield. The maximum milk yield was $2664.7 \mathrm{~kg}$ when calving interval was ranged from 13-15 months. These results agreed with (Sohail, 2010) found that a nonsignificant effect of calving interval on 305day milk yield. Days open had a non-significant effect on 305 day milk yield. The maximum milk yield was $2757.8 \mathrm{~kg}$ when days open was more than 160 days. The opposite results obtained by (Penchev et al., 2009) found that a significant effect of days open on the 305day milk yield. Number of services per conception and dry period had a non-significant effect on 305day milk yield. The highest yield was recorded for animals had four or more services and dry period less than 170 days $(2529.8 \mathrm{~kg}$ and
$2624.1 \mathrm{~kg}$, respectively). Season of calving had a highly significant effect $(P \leq 0.01)$ on 305 day milk yield. Winter season showed higher milk production than summer season $2600.5 \mathrm{~kg}$ and $2441.5 \mathrm{~kg}$, respectively). These results agreed with (Elmaghraby, 2010), (Thiruvenkadan et al., 2010) and (Pawar et al., 2012) who showed that that there was significant effect of the season on 305day milk yield. On the contrary, (Badran et al., 2002), (Sarkar et al., 2006) and (Sohail, 2010) noted that there was a non-significant effect of season of calving on 305day milk yield. Season of calving had a significant effect $(P \leq 0.05)$ on calving interval days open. calving interval and days open in summer (14.7 months and 134.2 days, respectively) was more than in winter season (14.5 months and 124.2 days, respectively).The obtained results were in the same line of those obtained by (Cady et al., 1983), (Shah et al., 1989), (Aziz et al., 2001) and (Marai et al., 2009) who reported that there was a significant effect of season of calving on calving interval and days open. On the contrary, (Marai et al., 2001) showed that season of calving had a non-significant effect on calving interval. Parity had a highly significant effect $(P \leq 0.01)$ on calving interval days open. With increasing parity number, calving interval and days open decreased. This results agreed with (Mahdy et al., 2001) and (Thiruvenkadan and Panneerselvam, 2010) who noted that parity had highly significant effects on calving interval and days open. On the contrary, parity had a non-significant effect on calving interval of buffalo (Marai et al., 2001) and (Mberato et al., 2016). Also, parity had a nonsignificant effect on days open (Hussain et al., 2006). Animals that produced less than $2000 \mathrm{~kg}$ of milk per season showed minimum number of services per conception (1.76), also showed maximum age at first service and age at first calving (23.2 and 37.3 months, respectively). There was direct relationship between milk yield 
with each of calving interval and days open. Animals that gave more than $3000 \mathrm{~kg}$ showed the maximum calving interval and days open (14 months and 111.8 days, respectively). Animals with high calving interval and days open may be due to low expression of estrous cycle or any breeding problem. These results agreed with (Zedian, 1990), (Ayesh, 1992), (Ali et al., 2000), (Atashi et al., 2013) and (Němečková et al., 2015) who showed that calving interval, days open and number of services per conception was higher in low producing cows than higher producing animals.

\section{REFERENCES}

Ali, A., Javed, K., Ahmad, N., Rehman, S.U., 2011. Environmental factors affecting some reproductive traits in Nili Ravi buffaloes. J. Anim. Plant Sci, 21(4), 868871.

Ali, A.K.A., Al-Haidary, A., Alshaikh, M.A., Gamil, M.H., Hayes, E., 2000. Effect of days open on the lactation curve of Holstein cattle in Saudi Arabia. Asian Aus. J. Anim. Sci. 13(3), 277-286.

APRI, 1997. Genetic dissection of phenotypic diversity in farm animals. Nature Reviews, Genetics. 2, 130-138.

Atashi, H., Zamiri, M.J., Akhlaghi, A.D., M.,, Sayyadnejad, M.B., Abdolmohammadi, A.R., 2013. Association between the lactation curve shape and calving interval in Holstein dairy cows of Iran. Iranian Journal of Veterinary Research, Shiraz University, 14(2), 88-93.

Ayesh, H., 1992. Some reproductive aspect of female buffaloes fed on dry feeds. Ph.D. Thesis, Fac. Agric. Ain-Shams Univ., Egypt.

Aziz, M.A., Schoeman, S.J., Jordaan, G.F., O.M., E.-C., Mahdy, A.T., 2001. Genetic and phenotypic variation of some reproductive traits in Egyptian buffalo. South African Journal of Animal Science 31(3), 195-199.

Badran, A.E., El-Barbary, A., Mahdy, A.E., Assar, G.M., 2002. Genetic and nongenetic factors affecting the lifetime production traits in Egyptian buffaloes. . Buffalo Journal. 18(2), 235-241.
Cady, R.A., Shah, S.K., Schermerhorn, E.C., Mcdowell, R.E., 1983. Factors affecting performance of Nili-Ravi buffaloes in Pakistan. . Factors affecting performance of Nili-Ravi buffaloes in Pakistan. 66, 578-586.

DAS-IS, 2004. Domestic Animal Diversity Information System www/fao.org.dad.-

Elmaghraby, M.M.A., 2010. Lactation persistency and prediction of total milk yield from monthly yields in Egyptian buffaloes. . Lucrari Stiintifice. Seria Zootehnie - Universitatea de Stiinte Agricole si Medicina Veterinara Ion Ionescu de la Brad 53(15), 130-137.

Eskandari, G., Karimpour, F., 2012. Genetic and Phenotypic Parameters Estimates of

Milk Yield Traits in Iranian Khuzestan Buffalos. Global Veterinaria 8 (1), 5153.

FAO, 2013. Food and Agriculture Organization ,faostat.fao.org/site/573/ default.aspx.

Hussain, Z., Javed, K., Hussainn, S.M.I., Kiyani, G.S., 2006. Reproductive performance of Nili-Ravi buffaloes in Azad Kashmir, pakistan. J. Anim. P1. Sci. 16(1-2), 15-19.

Mahdy, A.E., El-Shafie, O.M., El-Rigalaty , H.A., 2001. Relative importance of some factors affecting performance traits in a herd of Egyptian buffaloes. Alexandria Journal of Agricultural Research. 46(1), 1-18.

Marai, I.F.M., Daader, A.H., Soliman, A.M., El-Menshawy, S.M.S., 2009. Nongenetic factors affecting growth and reproduction traits of buffaloes under dry management housing (in sub-tropical environment) in Egypt. . Livestock Research for Rural Development 21.(3)

Marai, I.F.M., Farghal, H.M., Nasr, A.A., Abou -Fandoud, E., Mohamed, 1.A.S ,. .2001Buffalo cow productive, reproductive and udder traits and stayability under sub-tropical environmental conditions of Egypt. Journal of Agriculture in the Tropics and Subtropics 102, 1 -14.

Mberato, Y., Hamsun, M., Saloko, F., Mirajuddin., 2016. Effect of Non Genetic Factors on Calving Interval of 
Swamp Buffalo in Poso District, Indonesia. Aust. J. Basic \& Appl. Sci. 10(4), 187-192.

Mondal, S., Prakash, B.S., Palta, P., 2007. Endocrine aspects of estrous cycle in buffaloes (Bubalus bubalis). . AsianAust J Anim Sci. 1, 124 - 131.

Němečková, D., Stádník, L., Čítek, j., 2015. Associations between milk production level, calving interval length, lactation curve parameters and economic results in Holstein cows. Mljekarst 65(4), 243250.

Pawar, H.N., Kumar ,G.V.P.P.S.R., Narang, R., 2012. Effect of Year, Season and Parity on Milk Production Traits in Murrah Buffaloes. . Journal of Buffalo Science 1, 122-125.

Penchev, P., Llieva, Y., Peeva, T., 2009. Effects of days open on milk yield and the duration of the concurrent lactation in Bulgarian Murrah Buffaloes. Agricultural Science and Technology. 1(4), 117-120.

Sarkar, U., Gupta, A.K., Mohanty, T.K., Raina, V.S., Prasad, S., 2006. Genetic and non-genetic factors affecting milk yield and milk constituents in Murrah buffaloes. Dairying, Foods \& H.S. 25(2), 125-128.
SAS, 2001. statistical analysis system, User's Guide Computers by SAS Institute Inc., Cary, NC, USA.

Shah, S.N.H., Willemse, A.H., Van De Wiel, D.F.M., Engel, B., 1989. Influence of season and parity on several reproductive parameters in Nili-Ravi buffaloes in Pakistan. . Animal Reproduction Science 21, 177-190.

Sohail, S.M., 2010. Genetic evaluation of dairy buffaloes. PhD thesis. Faculty of Animal Husbandry and Veterinary Sciences, University of Agriculture, Faisalabad.

Thiruvenkadan, A.K., Panneerselvam, S., 2010. Milk production and reproductive performances of Murrah buffaloes in Tamil Nadu, India. . Sustainable improvement of animal production and health. , 99-104.

Thiruvenkadan, A.K., Panneerselvam, S., Rajendran, R., Murali, N., 2010. Analysis on the productive and reproductive traits of Murrah buffalo cows maintained in the Coastal region of India. South African society for animal science 3, 1-4.

Zedian, S.M., 1990. Study of productive performance of Egyptian buffaloes. M.Sc. Thesis, Moshtohor, Zagazig University, Egypt. 